\title{
Pemenuhan Hak Atas Informasi Masyarakat Dalam Pelaksanaan Pengadaan Tanah: Studi Pengadaan Tanah Taman Budaya Sleman
}

\author{
Siti Rahma Novikasari dan Nurmalita Ayuningtyas Harahap \\ Fakultas Hukum Universitas Islam Indonesia Yogyakarta Indonesia \\ Jln. Tamansiswa No. 158 Yogyakarta Indonesia \\ siti.rahma.novikasari@uii.ac.id; 154101306@uii.ac.id
}

Received: 17 Desember 2020; Accepted: 30 April 2021; Published: 2 Juni 2021

DOI: 10.20885/iustum.vol28.iss2.art9

\begin{abstract}
This research is aimed at examining the relationship between the implementation of the principle of openness of the government to the fulfillment of the right to information in the land acquisition activity of the Sleman Cultural Park. The problems in this research are, first, what is the concept of fulfilling the right to information in the land acquisition policy for the public interest? Second, does the implementation of the Sleman Cultural Park land acquisition reflect the fulfillment of the right to information? This study uses an empirical legal research method with a statutory approach and a conceptual approach. The results of the study concluded that in the implementation of the Sleman Cultural Park land acquisition, the fulfillment of the right to information by the government was limited to a formalistic framework and had not yet reached the fulfillment of the right to information substantially, so that the community did not have full rights to information. This has led to public distrust of the government and resulted in the failure of land acquisition activities for the Sleman Cultural Park.
\end{abstract}

Key Words: Cultural park; land procurement; right to information

\section{Abstrak}

Penelitian ini ditujukan untuk mengkaji relasi antara pelaksanaan asas keterbukaan pemerintah terhadap pemenuhan hak atas informasi dalam kegiatan pengadaan tanah taman budaya Sleman. Permasalahan dalam penelitian ini, pertama, bagaimana konsep pemenuhan hak atas informasi dalam kebijakan pengadaan tanah untuk kepentingan umum? Kedua, apakah implementasi pengadaan tanah taman budaya Sleman telah merefleksikan pemenuhan hak atas informasi? Penelitian ini menggunakan metode penelitian hukum empiris dengan pendekatan undang-undang dan pendekatan konseptual. Hasil kajian menyimpulkan bahwa pertama, dalam pelaksanaan pengadaan tanah taman budaya Sleman, pemenuhan hak atas informasi oleh pemerintah terbatas pada kerangka formalistas dan belum sampai pada pemenuhan hak atas informasi secara substansial. Kedua, masyarakat tidak mendapatkan hak atas informasi secara penuh. Hal ini menyebabkan ketidakpercayaan masyarakat terhadap pemerintah dan berakibat pada kegagalan kegiatan pengadaan tanah tamam budaya sleman.

Kata-kata Kunci: Hak atas informasi; pengadaan tanah; taman budaya 


\section{Pendahuluan}

Negara Kesatuan Republik Indonesia sebagai organisasi kekuasaan memiliki tujuan bernegara sebagai implikasi dari adanya kontrak sosial dengan masyarakat. Tujuan tersebut telah dirumuskan dalam Pembukaan UndangUndang Dasar Negara Republik Indonesia Tahun 1945. Pembangunan nasional merupakan upaya yang dilakukan oleh pemerintah, berupa rangkaian kegiatan pembangunan yang berkesinambungan dan tanpa henti untuk mencapai kesejahteraan masyarakat antargenerasi sebagai salah satu tujuan bernegara. ${ }^{1}$

Kebutuhan atas tanah meningkat dari waktu ke waktu dengan adanya program pembangunan nasional. ${ }^{2}$ Peraturan perundang-undangan disusun sebagai dasar hukum pelaksanaan pengadaan tanah untuk pembangunan nasional dengan orientasi keadilan, kemanfaatan, dan kepastian hukum. Sebagaimana doktrin hukum progresif dari Satjipto Rahardjo, hukum senantiasa berjalan tertatih-tatih di belakang manusia (metrecht hinkt achterde mens), ${ }^{3}$ begitu pula kebijakan pengadaan tanah mengalami berbagai perubahan untuk menyesuaikan diri dengan perkembangan masyarakat.

Pengejawantahan Hak Menguasai Negara dalam pelaksanaan pengaturan pengadaan tanah mengalami berbagai transformasi, mulai dari kebijakan konsepsi pencabutan hak atas tanah, ${ }^{4}$ pembebasan tanah, ${ }^{5}$ dan terakhir yaitu pengadaan tanah. ${ }^{6}$ Kebijakan pengadaan tanah dewasa ini diatur melalui Undang-Undang Nomor 2 Tahun 2012 tentang Pengadaan Tanah Bagi Pembangunan untuk Kepentingan Umum (UU Pengadaan Tanah). Transformasi kebijakan pengadaan tanah tersebut menunjukkan bahwa sifat hukum itu dinamis dan selalu mengikuti perkembangan masyarakat.

\footnotetext{
${ }_{1}^{1}$ M. Dari Arif Mu’allifin, Hubungan Konstitusi dengan Tugas dan Fungsi Negara, Jurnal Abkam, Vol 4, No. 1, Juli 2016, hlm. 162.

${ }^{2}$ Nabbilah Amir, Aspek Hukum Pengaturan Tata Ruang terhadap Alih Fungsi Lahan dalam Rangka Pembangunan Nasional, Justiciabelen, Vol 1 No 1, 2018, hlm. 128

${ }^{3}$ Satjipto Rahardjo, Reformasi Menjadi Hukum Progresif, Unisia, No. 53/XXVII/III/2004, hlm. 238.

${ }^{4}$ Lihat pengaturan Pasal 18 UUPA jo. Undang-Undang No. 20 Tahun 1961 tentang Pencabutan HakHak Atas tanah dan Benda-Benda yang ada di Atasnya

${ }^{5}$ Lihat Peraturan Menteri Dalam Negeri No. 15 Tahun 1975 tentang Ketentuan-Ketentuan Mengenai Tata Cara Pembebasan Tanah

6 Lihat Keputusan Presiden No. 55 Tahun 1993 tentang Pengadaan Tanah Bagi Pelaksanaan Pembangunan Untuk Kepentingan Umum jo. Peraturan Presiden No. 36 Tahun 2005 tentang Pengadaan Tanah Bagi Pelaksanaan Pembangunan untuk Kepentingan Umum jo. Undang-Undang No. 2 Tahun 2012 tentang Pengadaan Tanah Bagi Pembangunan untuk Kepentingan Umum
} 
Kebijakan pengadaan tanah yang saat ini digunakan memiliki muatan hak asasi manusia yang kental. Salah satunya adalah adanya jaminan hak atas informasi bagi pemegang hak atas tanah yang diatur dalam Pasal 55 UU Pengadaan Tanah, bahwa "dalam penyelenggaraan Pengadaan Tanah, Pihak yang Berhak mempunyai hak: a) mengetahui rencana penyelenggaraan Pengadaan Tanah dan b) memperoleh informasi mengenai Pengadaan Tanah."

UU Pengadaan Tanah juga mengatur tindakan pemerintah berdasarkan asas-asas pengadaan tanah yang tidak diatur dalam kebijakan sebelumnya sebagai sebuah jaminan pemenuhan hak atas informasi bagi masyarakat. Pengaturan asas-asas pengadaan tanah koheren dengan asas umum pemerintahan yang baik. Untuk menjalankan kewajiban pemenuhan hak atas informasi, dalam pelaksanaan pengadaan tanah Pemerintah wajib merujuk asas keterbukaan yang dinormakan dalam Pasal 16 UU Pengadaan Tanah, bahwa "instansi yang memerlukan tanah bersama pemerintah provinsi berdasarkan dokumen perencanaan pengadaan tanah melaksanakan a) pemberitahuan rencana pembangunan; b) pendataan awal lokasi pembangunan; dan c) konsultasi publik rencana pembangunan."

Penerapan asas keterbukaan untuk memenuhi hak atas informasi masyarakat pada praktiknya tidak berjalan secara harmonis. Secara umum, tidak terpenuhinya hak atas informasi kerap kali menjadi salah satu faktor pemicu konflik vertikal antara instansi yang memerlukan tanah (pemerintah) dan pemilik hak atas tanah (masyarakat), ${ }^{7}$ serta kegagalan penyelenggaraan pengadaan tanah seperti yang terjadi pada kasus pengadaan tanah Taman Budaya Sleman di Desa Sidoluhur Kecamatan Godean yang diselenggarakan oleh Dinas Kebudayaan Kabupaten Sleman. ${ }^{8}$

Persiapan pengadaan tanah pada kasus pengadaan tanah Taman Budaya Sleman di Desa Sidoluhur Kecamatan Godean, sudah berlangsung sejak sekitar awal 2018 hingga 2019. Kegiatan persiapan pengadaan tanah yang dilakukan oleh Dinas Kebudayaan Pemerintah Kabupaten Sleman tersebut sebenarnya sudah

7 Iga Gangga Santi Dewi, Konflik Tentang Ganti Rugi Non Fisik Pada Pengadaan Tanah Untuk Kepentingan Umum, Masalah-Masalab Hukum, Vol. 46, No 3, 2017, hlm. 289.

8 Nn, Pembangunan Taman Budaya Sleman Masih Mencari Tanah https://jogja.tribunnews.com/2019/06/27/pembangunan-taman-budaya-sleman-masih-mencari-tanah diakses pada 11 Februari 2020 
melewati tahapan akhir sosialisasi dan konsultasi publik untuk mencapai permufakatan atas ganti kerugian. Namun, dalam pelaksanaan seluruh agenda persiapan pengadaan tanah, tidak semua informasi didapatkan oleh masyarakat pemilik hak atas tanah, seperti informasi tentang pelaksanaan pengadaan tanah, terutama pada prosedur, bentuk dan besaran ganti kerugian. ${ }^{9}$ Hal ini berujung pada tidak tercapainya mufakat antara instansi yang memerlukan tanah dengan masyarakat pemegang hak atas tanah.

\section{Rumusan Masalah}

Berdasarkan permasalahan di atas, rumusan masalah yang akan dikaji dalam penelitian ini, pertama, bagaimana konsep pemenuhan hak atas informasi dalam kebijakan pengadaan tanah untuk kepentingan umum? Kedua, apakah implementasi pengadaan tanah Taman Budaya Sleman telah merefleksikan pemenuhan hak atas informasi?

\section{Tujuan Penelitian}

Fokus tujuan dalam riset ini yaitu untuk menemukan hal-hal sebagai berikut. Pertama, untuk mengetahui konsep pemenuhan hak atas informasi dalam kebijakan pengadaan tanah untuk kepentingan umum. Kedua, untuk mengetahui bahwa implementasi pengadaan tanah Taman Budaya Sleman telah merefleksikan pemenuhan hak atas informasi.

\section{Metode Penelitian}

Penelitian ini merupakan penelitian hukum empiris yang merupakan penelitian hukum mengenai pemberlakukan atau implementasi hukum normatif secara in action terhadap suatu peristiwa hukum dalam masyarakat. Studi lapangan untuk mendapatkan data primer, dengan menggunakan metode wawancara dan kuisioner kepada tujuh responden pemegang hak atas tanah di lokasi pengadaan tanah untuk Taman Budaya Sleman. Pemilihan responden menggunakan metode purposive sampling. Sedangkan data skunder berupa bahan hukum primer, skunder dan tersier didapatkan melalui studi kepustakaan.

\footnotetext{
${ }^{9}$ Wawancara dengan Ibu Endang sebagai masyarakat terdampak pengadaan tanah, pada 24 Januari 2020
} 
Pendekatan yang digunakan dalam penelitian ini adalah pendekatan undangundang (statute approach) dan pendekatan konseptual (concept approach).

\section{Hasil Peneltian dan Pembahasan}

\section{Hak Atas Informasi dalam Kebijakan Pengadaan Tanah untuk Kepentingan Umum}

Indonesia sebagai negara hukum telah dengan jelas disebutkan dalam Pasal 1 ayat (3) Undang-Undang Dasar Negara Republik Indonesia Tahun 1945. Dalam perkembangan konsepsi negara hukum dalam tradisi Anglo Saxon (the rule of law), A.V. Dicey memberikan pandangan bahwa salah satu ciri penting yang ada dalam setiap negara hukum adalah perlindungan hak asasi manusia yang dijamin oleh konstitusi. ${ }^{10}$ Friedrich Julius Stahl juga menyebutkan bahwasanya perlindungan hak asasi manusia merupakan elemen penting dalam konsep negara hukum rechstaat dalam tradisi eropa kontinental. ${ }^{11}$

Definisi yuridis hak asasi manusia yakni seperangkat hak yang melekat pada hakikat keberadaan manusia sebagai makhluk Tuhan yang Maha Esa dan merupakan anugerah-Nya yang wajib dihormati, dijunjung tinggi, dan dilindungi oleh negara, hukum, pemerintah, dan setiap orang demi kehormatan serta perlindungan harkat dan martabat. Maka, sebuah ciri suatu negara sebagai negara hukum adalah adanya pengakuan, penghormatan, dan perlindungan hak asasi manusia. ${ }^{12}$ Salah satu hak dasar yang dimiliki oleh manusia adalah hak atas informasi. Dalam perkembangan pemikiran hak asasi manusia, hak atas informasi merupakan hak-hak generasi pertama yang berkaitan dengan hak sipil dan politik. ${ }^{13}$

10 A.V. Dicey memberikan tiga ciri negara hukum (rule of law) yaitu supremasi hukum (supremacy of law), adanya kedudukan yang sama di depan hukum (equity before the law) dan penegasan perlindungan hak asasi manusia dalam konstitusi (contitutional based on individual rights and enforced by the courts) dalam A. Muhammad Asrun, "Hak Asasi Manusia dalam Kerangka Cita Negara Hukum (Catatan Perjuangan di Mahkamah Konstitusi)", Jurnal Cita Hukum Fakultas Syariah dan Hukum UIN Jakarta, Vol. 4 No. 1 (2016), hlm. 139.

11 Friedrich Julius Stahl menegaskan elemen penting dalam negara hukum (rechstaat) yakni adaya perlindungan hak asasi manusia, adanya pemisahan atau pembagian kekuasaan, pemerintahan berdasarkan peraturan-peraturan (wetmatigheid van bestuur), dan adanya peradilan administrasi yang bebas dalam perselisihan. Dalam Sayuti, "Konsep Rechstaat dalam Negara Hukum Indonesia", Jurnal Kajian Ekonomi Islam dan Kemasyarakatan, Volume 4, Nomor 2, Desember 2011, hlm. 24-25.

${ }^{12}$ B. Arief Sidharta, Kajian Kefilsafatan tentang Negara Hukum, dalam Jentera (Jurnal Hukum), "Rule of Law”, Pusat Studi Hukum dan Kebijakan (PSHK), Jakarta, edisi 3 Tahun II, November 2004, hal.124-125.

13 Jefri Porkonanta Taringan, "Akomodasi Politik Hukum di Indonesia Terhadap Hak Asasi Manusia Berdasarkan Generasi Pemikirannya”, Jurnal Konstitusi, Volume 14, Nomor 1, Maret 2017, hlm 175. 
Salah satu wujud pemenuhan hak atas informasi adalah melalui amandemen konstitusi (1999-2000), hal ini mencerminkan fungsi konstitusi sebagai Guardian of Fundamental Rights atau perlindung hak-hak fundamental. ${ }^{14}$ Hak atas informasi diatur dalam Pasal 28F Undang-Undang Dasar Negara Republik Indonesia Tahun 1945 (UUD 1945), “setiap orang berhak untuk berkomunikasi dan memperoleh Informasi untuk mengembangkan pribadi dan lingkungan sosialnya, serta berhak untuk mencari, memperoleh, memiliki, dan menyimpan Informasi dengan menggunakan segala jenis saluran yang tersedia."

Konsekuensi logis dari pengaturan hak asasi manusia oleh sebuah negara adalah timbulnya prinsip kewajiban postif. ${ }^{15}$ Berdasarkan prinsip kewajiban positif tersebut, maka negara sebagai pemanggku kewajiban (duty bearer) memiliki kewajiban terhadap kelompok masyarakat pemegang hak (rights holder) untuk memberikan perlindungan (protect) dan pemenuhan (fullfill). ${ }^{16}$

Jaminan pemenuhan hak atas informasi bagi masyarakat perlu dilakukan oleh pemerintah Indonesia dengan menerapkan keterbukaan (openbaarheid) dan keterbukaan pemerintahan (openbaarheid van bestuur) sebagai salah satu corak negara demokratis yang menjunjung tinggi kedaulatan rakyat. ${ }^{17}$ Dewasa ini, keterbukaan telah menjadi sebuah asas hukum dalam bidang Hukum Administrasi Negara yang dikenal dengan Asas Umum Pemerintahan yang Baik (AUPB). Terdapat beberapa asas-asas umum (hukum pemerintahan), yaitu asas keabsahan (rechtmatigheid van bestuur), asas efisiensi dan efektifitas (doelmatigheid en doeltreffendheid), asas keterbukaan (openbaarheid van bestuur), dan asas berencana (planmatigheid) dalam menjalankan pemerintahan. ${ }^{18}$

Penerapan asas keterbukaan (openbaarheid van bestuur) dalam suatu negara hukum modern (welfare state) ditujukan untuk mewujudkan pertanggungjawaban

\footnotetext{
${ }^{14}$ Bagir Manan dan Susi Dwi Harijanti, "Konstitusi dan Hak Asasi Manusia”, Jurnal Ilmu Hukm, Volume 3, Nomor 3, Tahun 2016, hlm. 456.

15 Andrey Sujatmoko, 2016, Hukum HAM dan Hukum Humaniter, PT Rajagrafindo Persada, Jakarta, hlm. 12

${ }^{16}$ Morten Broberg dan Hans-Otto Sano, "Strengths and weaknesses in a human rightsbased approach to international development - an analysis of a rights-based approach to development assistance based on practical experiences", The International Journal of Human Rights, Vol. 22, No. 5, 2017, hlm. 669.

17 Ridwan, Arti Penting Asas Keterbukaan dalam Penyelenggaraan Pemerintahan yang Bebas dari Korupsi, Kolusi, dan Nepotism, Jurnal Hukum, Vol. 27, 11 September 2004, hlm. 52.

18 Aditia Syaprillah, Penegakan Hukum Administrasi Lingkungan Melalui Instrumen Pengawasan, Jurnal Bina Hukum Lingkungan, Volume 1, Nomor 1, Oktober 2016, hlm.103.
} 
pemerintah terhadap warga negaranya. Transparansi penyelenggaraan pemerintahan memberikan kesempatan kepada masyarakat untuk mengetahui kebijakan yang akan dan telah diambil oleh pemerintah. Melalui transparansi penyelenggaraan pemerintahan tersebut juga, masyarakat dapat memberikan feedback atau outcomes terhadap kebijakan yang telah diambil oleh pemerintah. ${ }^{19}$ Merujuk pada penjelasan Pasal 10 huruf F Undang-Undang Nomor 30 Tahun 2014 tentang Administrasi Pemerintahan (UU Administrasi Pemerintahan), dijelaskan bahwa "asas Keterbukaan dalam AUPB dimaksud sebagai asas yang melayani masyarakat untuk mendapatkan akses dan memperoleh informasi yang benar, jujur, dan tidak diskriminatif dalam penyelenggaraan pemerintahan dengan tetap memperhatikan perlindungan atas hak asasi pribadi, golongan, dan rahasia negara."

Transparansi menurut Mardiasmo berarti keterbukaan (opennsess) pemerintah dalam memberikan informasi yang terkait dengan aktivitas pengelolaan sumber daya publik kepada pihak-pihak yang membutuhkan informasi.20 Keterbukaan dibangun atas dasar informasi yang bebas. Seluruh proses pemerintahan, lembaga-lembaga, dan informasi perlu dapat diakses oleh pihak-pihak yang berkepentingan, dan informasi yang tersedia harus memadai agar dapat dimengerti dan dipantau. Namun demikian, tidak berarti semua informasi dapat dibuka dan diakses oleh publik. Jadi, keterbukaan untuk memperoleh akses informasi bukan sebebas-bebasnya tanpa batas tetapi dengan batas-batasnya dalam undang-undang. ${ }^{21}$

Hak atas informasi dan penerapan asas keterbukaan dalam kegiatan pengadaan tanah untuk kepentingan umum telah diatur dalam UU Pengadaan Tanah. Dapat disimpulkan bahwa pemenuhan hak atas informasi dalam konteks normatif telah dilakukan oleh pemerintah, yang mana masyarakat pemegang hak

19 BKSI, Mencari Format Dan Konsep Transparansi Dalam Penyelenggaraan Pemerintahan Daerah" Disajikan pada seminar "Menciptakan Transparansi Penyelenggaraan Pemerintahan Daerah : Memberdayakan Momentum Reformasi, Makalah, Forum Inovasi dan Kepemerintahan yang Baik, Program Pascasarjana, Program Studi Ilmu Administrasi, Fakultas Ilmu Sosial dan Ilmu Politik, Universitas Indonesia, Depok, 12 Juni 2001.

${ }^{20}$ Mardiasmo, 2004, Otonomi \& Manajemen Keuangan Daerah, Penerbit ANDI, Yogyakarta, hlm. 30.

21 A'an Efendi dan Freddy Purnomo, 2017, Hukum Administrasi, Sinar Grafika, Jakarta, hlm. 173. 
atas tanah memiliki hak untuk mengetahui rencana penyelenggaraan pengadaan tanah dan memperoleh informasi mengenai pengadaan tanah.

Informasi yang berhak didapatkan oleh masyarakat pemegang hak atas tanah dalam kegiatan rencana penyelenggaraan pengadaan tanah dan pelaksanaan pengadaan tanah, antara lain:

Tabel 1

Informasi Kegiatan Rencana dan Pelaksanaan Pengadaan Tanah

\begin{tabular}{|c|c|c|}
\hline No. & $\begin{array}{l}\text { Pasal dalam UU } \\
\text { Pengadaan Tanah }\end{array}$ & Informasi \\
\hline 1 & Pasal 14 & $\begin{array}{l}\text { Penyelenggara pengadaan tanah atau instansi yang } \\
\text { membutuhkan tanah }\end{array}$ \\
\hline 2 & Pasal 15 (1) & Tujuan pengadaan tanah \\
\hline \multirow[t]{2}{*}{3} & Pasal $15(1)$ & Kesesuaian rencana pengadaan tanah dengan Rencana \\
\hline & & $\begin{array}{l}\text { Tata Ruang Wilayah, Rencana Pembangunan } \\
\text { Nasional/Daerah, Rencana Strategis dan Rencana Kerja } \\
\text { setiap Instansi yang memerlukan tanah. }\end{array}$ \\
\hline 4 & Pasal $15(2)$ & $\begin{array}{l}\text { Perencanaan pengadaan tanah yang disusun dalam } \\
\text { bentuk dokumen berdasarkan studi kelayakan }\end{array}$ \\
\hline 5 & Pasal 16 & Agenda persiapan pengadaan tanah \\
\hline 6 & Pasal 18 & Proses penetapan lokasi \\
\hline 7 & Pasal 20 dan 23 & Hak mengajukan keberatan \\
\hline 8 & Pasal 31-36 & Penilaian ganti kerugian \\
\hline 9 & Pasal 40-41 & Pelaksanaan pemberian ganti kerugian \\
\hline 10 & Pasal 52 & sumber pendanaan pengadaan tanah \\
\hline
\end{tabular}

Pemenuhan hak atas informasi dalam ranah hukum administrasi negara merupakan sebuah kewajiban bagi pemerintah. Pemerintah dalam hal ini adalah instansi yang membutuhkan tanah. Tindakan pemerintah tersebut telah diberikan rambu-rambu dalam UU Pengadaan Tanah berupa asas keterbukaan. Asas keterbukaan menjadi salah satu asas penting yang diatur dalam Pasal 2 huruf e UU Pengadaan Tanah dan penjelasannya, bahwa "Pengadaan Tanah untuk Kepentingan Umum dilaksanakan berdasarkan asas keterbukaan." "Yang dimaksud dengan asas keterbukaan adalah bahwa pengadaan tanah untuk pembangunan dilaksanakan dengan memberikan akses kepada masyarakat untuk mendapatkan informasi yang berkaitan dengan Pengadaan Tanah." 
Sudikno Mertokusumo ${ }^{22}$ berpendapat bahwa asas bukanlah kaidah hukum konkrit, melainkan latar belakang peraturan yang konkrit dan bersifat umum atau abstrak. Dalam setiap asas hukum, dapat dilihat suatu cita-cita hukum itu sendiri. Hal ini menunjukkan bahwa asas keterbukaan memiliki peran yang krusial atas penyelenggaraan pengadaan tanah oleh pemerintah pusat maupun pemerintah daerah. Cita hukum dari asas pengadaan tanah yang telah dinormakan dalam UU Pengadaan Tanah yakni memberikan arahan bagi pemerintah dalam menjalankan tindakan administrasi pemerintahan serta sebagai jaminan bagi masyarakat dalam pemenuhan hak atas informasi.

Pelaksanaan asas keterbukaan dalam pengadaan tanah untuk memenuhi hak atas informasi bagi pemegang hak atas tanah dapat dilakukan melalui beberapa kegiatan sebagaimana diatur dalam Peraturan Presiden No. 71 Tahun 2012 tentang Penyelenggaraan Pengadaan Tanah Bagi Pembangunan Untuk Kepentingan Umum sebagaimana terakhir diubah terakhir dengan Peraturan Presiden No. 30 Tahun 2015 (Perpres Pengadaan Tanah) sebagai peraturan teknis dari UU Pengadaan Tanah. Keterbukaaan informasi dilakukan oleh pemerintah melalui:

a. Pemberitahuan rencana pembangunan yang dapat dilakukan secara langsung dengan kegiatan sosialisasi, tatap muka dan surat pemberitahuan. ${ }^{23}$

b. Konsultasi publik rencana pembangunan yang merupakan kegiatan dialogis antara pemerintah dengan pemegang hak atas tanah, yang ditujukan untuk mendapatkan kesepakatan lokasi. ${ }^{24}$

c. Musyawarah penetapan bentuk ganti kerugian. Musyawarah ini dilakukan secara langsung antara pemerintah dengan pemegang hak atas tanah untuk menetapkan bentuk dan besarnya ganti kerugian berdasarkan hasil penilaian ganti kerugian. ${ }^{25}$

Proses pengadaan tanah dilakukan dengan musyawarah para pihak tanpa ada unsur paksaan untuk mendapatkan kesepakatan bersama. Dasar kesepakatan para pihak ini terdapat baik dalam tahap persiapan maupun dalam tahap

\footnotetext{
22 Sudikno Mertokusumo, 2007, Mengenal Hukum Suatu Pengantar, Liberty, Yogyakarta, hlm. 403.

${ }^{23} \mathrm{Hal}$ ini sebagaimana diatur dalam Pasal 12 Perpres Pengadaan Tanah

${ }^{24}$ Hal ini sebagaimana diatur dalam Pasal 29-33 Perpres Pengadaan Tanah

${ }^{25}$ Hal ini sebagaimana diatur dalam Pasal 68-72 Perpres Pengadaan Tanah
} 
pelaksanaan untuk mendapatkan kesepakatan bersama. ${ }^{26}$ Sehingga asas keterbukaan dan asas kesepakatan menjadi dua dasar pelaksanaan pengadaan tanah bagi kepentingan umum yang tidak dapat dipisahkan.

\section{Pemenuhan Hak Atas Informasi dalam Pengadaan Tanah Taman Budaya Sleman}

UU Pengadaan tanah mengatur adanya relasi antara pemenuhan hak atas informasi dengan keterbukaan pemerintah untuk dapat mencapai tujuan dari pengadaan tanah. Pemenuhan Hak Atas Informasi dalam Kegiatan Pengadaan Tanah untuk Kepentingan Umum ditinjau dari 3 agenda antara intansi yang memerlukan tanah Dinas Kebudayaan Pemerintah Kabupaten Sleman dengan pemilik hak atas tanah, yakni kegiatan pemberitahuan rencana pembangunan, konsultasi publik dan musyawarah penetapan ganti kerugian.

Pada agenda pemberitahuan rencana pembangunan yang dilakukan oleh Tim Persiapan, keseluruhan responden ${ }^{27}$ mendapatkan informasi umum terkait dengan maksud dan tujuan rencana pembangunan, letak dan luas tanah yang dibutuhkan. Disamping itu Tim Persiapan juga memberikan pemaparan terkait dengan agenda dan mekanisme serta perkiraan jangka waktu pelaksanaan pengadaan tanah hingga pembangunan.

Tabel 2.

Informasi dalam agenda Pemberitahuan Rencana Pembangunan

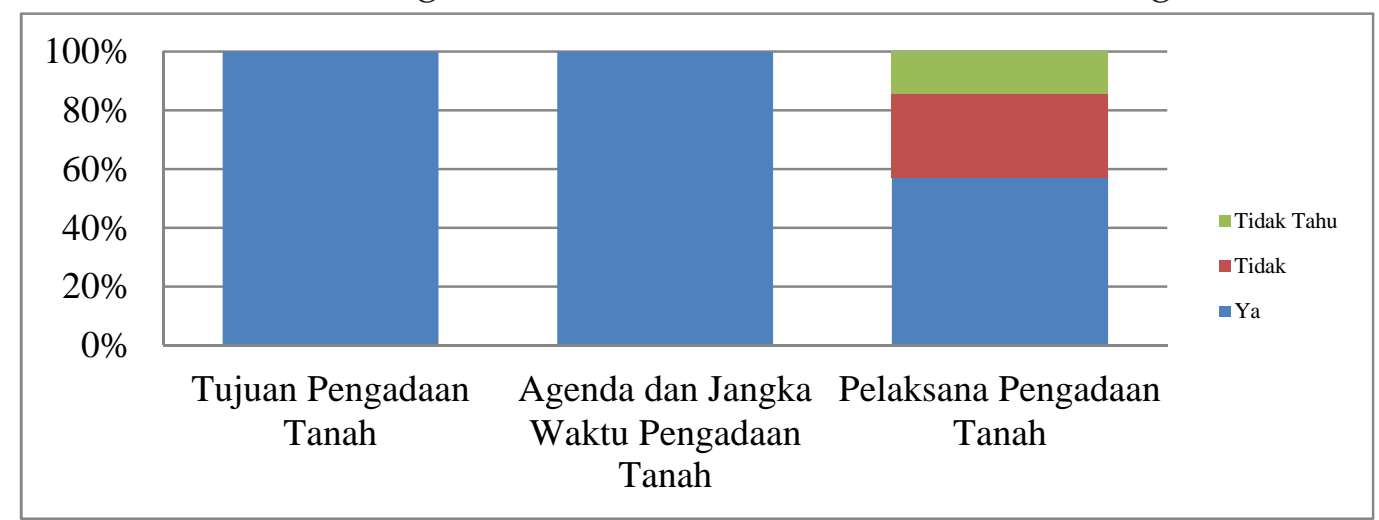

Sumber: Diolah sendiri oleh penulis dari hasil kuisioner

${ }^{26}$ Djoni Sumardi Gozali, 2018, Hukum Pengadaan Tanah (Asas Kesepakatan dalam Pengadaan Tanah bagi Pembangunan untuk Kepentingan Umum), UII Press, Yogyakarta, hlm.22.

${ }_{27}$ Terdapat 7 responden yang merupakan pemegang hak atas tanah dalam kegiatan Pengadaan Tanah Taman Budaya Sleman. 
Informasi tersebut disampaikan secara langsung dalam kegiatan sosialiasi di Kantor Kelurahan Desa Sidolohur. Tahap awal sosialisasi dimulai dari penyampaian tujuan dari adanya pengadaan tanah. Tujuan diadakannya pengadaan ini jelas diketahui oleh masyarakat terdampak pengadaan tanah untuk pembangunan Taman Budaya Sleman. Selain itu, diberikan juga informasi tentang agenda dan jangka waktu pengadaan tanah. Namun, agenda maupun jangka waktu yang diinformasikan tidak mendetail. Tim Persiapan hanya memberikan informasi terkait dengan rentang waktu dimulainya hingga diselesaikannya proses pengadaan tanahnya, yaitu awal 2018 sampai awal 2019.28

Tahap pemberitahuan rencana pembangunan Taman Budaya Sleman. Terdapat $42,9 \%$ responden menyatakan tidak memiliki informasi terkait dengan Pelaksana Pengadaan Tanah dan Tim Persiapan Pengadaan Tanah Dinas Kebudayaan Kabupaten Sleman tidak memberikan informasi yang komprehensif kepada masyarakat terkait dengan instansi-intasnsi terkait dan tim yang dibentuk dalam melaksanakan kegiatan persiapan pengadaan tanah, serta tugas dan fungsi dan masing-masing stakeholder tersebut.

Tabel 3.

Informasi Ganti Kerugian dalam agenda Konsultasi Publik

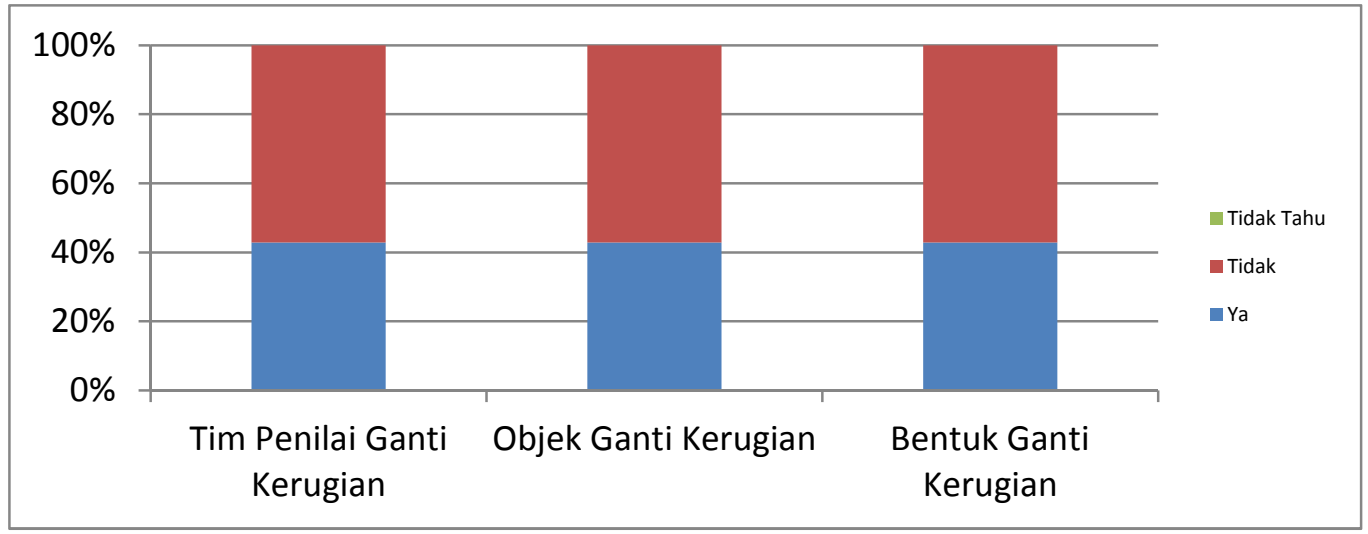

Sumber: diolah sendiri oleh penulis dari hasil kuisioner

Proses komunikasi antara tim persiapan pengadaan tanah dan pemengang hak atas tanah dilakukan secara dialogis pada agenda konsultasi publik. Tujuan dari pelaksanaan konsultasi publik adalah untuk mencapai kesepahaman dan kesepakatan dalam perencanaan pengadaan tanah dan pembangunan. Agenda ini

${ }^{28}$ Wawancara dengan Ibu NN (disamarkan), sebagai masyarakat terdampak pengadaan tanah, pada 26 Januari 2020. 
dilakukan lebih dari satu kali adanya dinamika konsultasi publik antara masyarakat dan tim persiapan. Selain memberikan penjelasan ulang terkait dengan tujuan dan tahapan pengadaan tanah sebagaimana telah dilaksanakan dalam agenda sosialisai, berbagai informasi kegiatan rencana dan pelaksanaan pengadaan tanah perlu disampaikan oleh tim persiapan.

Peneliti menemukan adanya konsistensi, bahwa 57,1\% responden tidak mendapakan informasi yang konprehensif terkait dengan aspek-aspek ganti kerugian dalam pengadaan tanah. Sebagaimana telah diatur dalam Pasal 32 Perpres Pengadaan Tanah, terdapat tiga aspek ganti kerugian yang harus dijelaskan oleh tim persiapan, yaitu:

a. Tim Penilai Ganti Kerugian

Besaran ganti kerugian dinilai oleh tim penilai ganti kerugian. Pemegang hak atas tanah memiliki hak untuk mendapatkan informasi terkait dengan kompetensi dan metode penetapan atau penunjukkan ganti kerugian.

b. Objek Ganti Kerugian

Objek ganti kerugian tidak hanya tanah, melaikan juga ruang atas tanah dan bawah tanah, bangunan, tanaman, benda yang berkaitan dengan tanah dan kerugian lain yang dapat dinilai

c. Bentuk Ganti Kerugian

Masyarakat berpandangan bahwa bentuk ganti kerugian adalah uang dalam bentuk rupiah, sehingga menjadi kewajiban bagi tim penilai untuk memberikan informasi bahwa terdapat bentuk ganti kerugian lain yang dapat diberikan seperti tanah pengganti, pemukiman kembali, kepemilikan saham, maupun bentuk lain yang disetujui oleh kedua belah pihak.

Aspek ganti kerugian hakikatnya adalah substansi yang tidak pernah hilang dalam definisi yuridis maupun pengaturan secara umum pada setiap bentuk kebijakan pengadaan tanah. Ganti kerugian bersifat esensial dan wajib diberikan kepada pemegang hak. Penentuan bentuk dan jumlah ganti kerugian menjadi aspek penting yang mampu meningkatkan kesejahteraan ekonomi bagi pelepas 
hak. ${ }^{29}$ Infomasi mengenai ganti kerugian harus disampaikan secara komprehensif sebagai bentuk pemenuhan hak atas informasi masyarakat.

Terdapat satu informasi lain yang wajib disampaikan oleh tim persiapan pengadaan tanah dalam agenda konsultasi publik, yaitu hak dan kewajiban pihak pemegang hak atas tanah. Kajian ini menyoroti penyampaian informasi salah satu hak fundamental yang merepresentasikan prinsip equity before the law yaitu mengajukan upaya hukum keberatan dan gugatan.

Tabel 4.

Informasi Hak Mengajukan Upaya Hukum Keberatan dan Banding

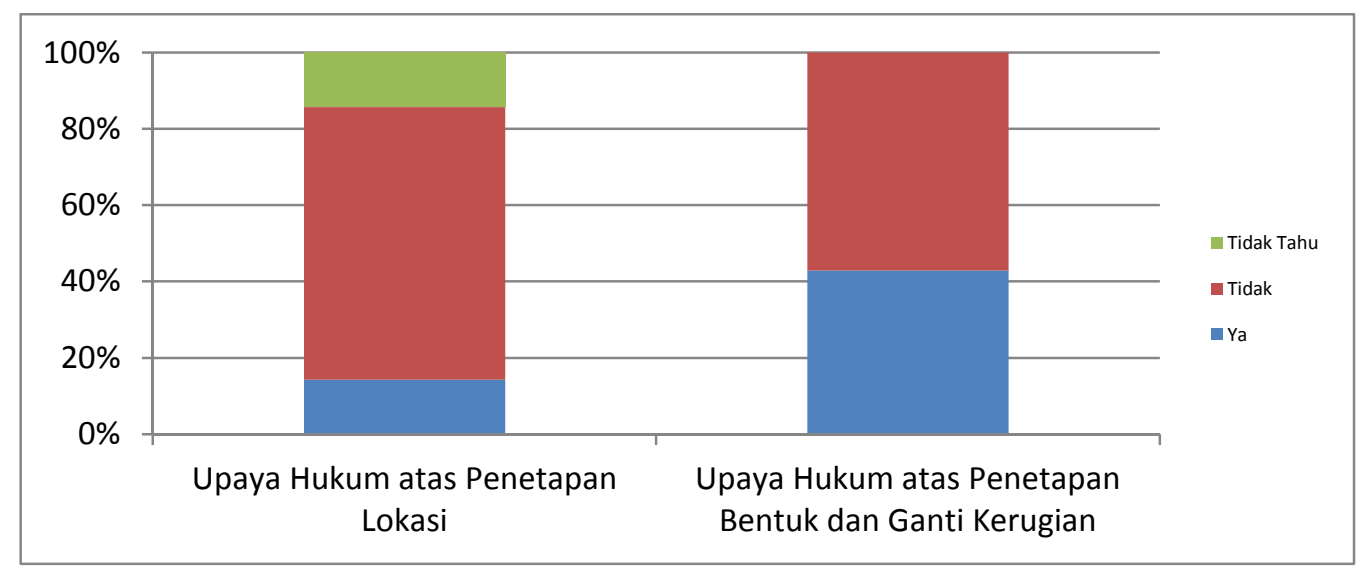

Sumber: Diolah sendiri oleh penulis dari hasil kuisioner

Sebanyak 14,6\% responden mendapatkan informasi untuk mengajukan keberatan dan gugatan tata usaha negara atas penetapan lokasi pembangunan. Sedangkan $42,9 \%$ responden menyatakan telah mendapatkan informasi untuk mengajukan keberatan pada pengadilan negeri setempat apabila tidak terjadi kesepakatan mengenai bentuk dan/atau besarnya ganti kerugian.

Kegiatan terakhir dalam persiapan pengadaan tanah yakni agenda musyawarah penetapan bentuk ganti kerugian yang dilakukan oleh Pelaksana Pengadaan Tanah bersama dengan Instansi yang memerlukan tanah. Melalui agenda ini, diharapkan dapat tercapai mufakat atas bentuk dan nilai ganti kerugian berdasarkan hasil penilaian ganti kerugian. Masyarakat aktif berdialog dan mempertanyakan informasi tentang mekanisme penilaian ganti kerugian kepada pelaksana pengadaan tanah. Namun, dalam pelaksanaannya, $71,4 \%$

${ }^{29}$ Lihat Yul Ernis, 2015, Pelaksanaan Pengadaan Tanah Bagi Pembangunan untuk Kepentingan Umum, Badan Pembinaan Hukum Nasional, Kementerian Hukum dan HAM, Jakarta, hlm. 38. 
responden menyatakan bahwa pelaksana pengadaan tanah tidak memberikan informasi mekanisme penilaian hingga sampai pada nilai ganti kerugian yang diperkirakan. Dalam agenda musyawarah tersebut, hanya disampaikan perkiraan harga tanah yang variatif antara Rp.350.000,00 sampai Rp.750.000,00 per meter, tanpa menunjukkan dokumen perhitungan yang dilakukan oleh tim penilai ganti kerugian.

Penulis menyimpulkan bawa hak atas informasi masyarakat tidak terpernuhi dalam tiga agenda persiapan pengadaan tanah Taman Budaya Sleman. Keterbukaan sejauh ini hanya dimaknai sebagai keterbukaan formil dengan memberikan informasi dalam forum-forum yang diatur dalam UU Pengadaan Tanah dan aturan pelaksananya. Keterbukaan tidak diimplementasi dalam konteks keterbukaan materiil yaitu memberikan informasi yang secara substansial merupakan hak dari masyarakat.

Pelaksanaan pengadaan tanah oleh pemerintah yang dilakukan tidak berdasarkan asas keterbukaan sebagaimana diatur dalam UU Pengadaan Tanah dan UU Administrasi Pemerintahan mengakibatkan tidak terpenuhinya hak atas informasi dari masyarakat. Pengadaan tanah Taman Budaya Sleman mejadi salah satu contoh adanya relasi antara penerapan asas keterbukaan terhadap pemenuhan hak atas informasi tersebut. Dapat ditarik kesimpulan bahwa pemerintah yang tidak terbuka atas pelaksanaan pengadaan tanah mengakibatkan masyarakat kekurangan informasi sehingga meningkatkan level ketidakpercayaan (distrust) dari masyarakat kepada pemerintah yang berakibat pada kegagalan pelaksanaan pengadaan tanah.

\section{Penutup}

Berdasarkan hasil penelitian dan pembahasan yang telah diuraikan, maka dapat disimpulkan bahwa: Pertama, konsep pemenuhan hak atas informasi dalam kebijakan pengadaan tanah untuk kepentingan umum tercermin di dalam UU Pengadaan Tanah, yang merupakan kebijakan sektoral yang kental atas norma hak asasi manusia, salah satunya adalah hak atas informasi. Konsep pemenuhan hak atas informasi terlihat dari kewajiban Pemerintah (duty bearer) untuk melakukan perlindungan dan pemenuhan hak atas informasi kepada masyarakat 
pemegang hak atas tanah (right holder). Pelaksanaan pengadaan tanah untuk kepentingan umum berdasar juga pada asas-asas sebagai rambu-rambu dalam melakukan tindakan pemerintah, salah satunya asas keterbukaan. Hak atas informasi bagi masyarakat yakni terkait dengan informasi kegiatan rencana dan pelaksanaan pengadaan tanah. Hak atas informasi dapat dipenuhi oleh pemerintah apabila dalam pelaksanaan pengadaan tanah, pemerintah bertindak terbuka dalam memberikan informasi kepada masyarakat.

Kedua, hasil studi lapangan menunjukkan bahwa ada keterbatasan informasi yang didapat oleh masyarakat terkait dengan kegiatan rencana dan pelaksanaan pengadaan tanah Taman Budaya Sleman, khususnya terkait dengan informasi ganti kerugian dan hak-hak mengajukan upaya hukum. Mayoritas responden menyatakan tidak mendapatkan informasi. Pemerintah dalam melakukan pengadaan tanah Taman Budaya Sleman cenderung mengimplementasikan asas keterbukaan dan melakukan pemenuhan hak atas informasi secara formalitas, dengan justifikasi kegiatan sosialisasi hingga konsultasi publik telah dilaksanakan. Namun, keterbukaan pemerintah dan pemenuhan hak atas informasi belum diimplementasikan secara substansial sesuai kaidah materiil yang diatur dalam peraturan perundang-undangan. Masyarakat tidak mendapatkan infromasi sesuai haknya dan berujung pada kegagalan proses pengadaan tanah karena tidak tercapai mufakat antara masyarakat dan pemerintah.

\section{Daftar Pustaka}

\section{Buku}

Efendi, A'an dan Freddy Purnomo, Hukum Administrasi, Sinar Grafika, Jakarta, 2017

Ernis, Yul, Pelaksanaan Pengadaan Tanah Bagi Pembangunan untuk Kepentingan Umum, Badan Pembinaan Hukum Nasional, Kementerian Hukum dan HAM, Jakarta, 2015

Gozali, Djoni Sumardi, Hukum Pengadaan Tanah (Asas Kesepakatan dalam Pengadaan Tanah bagi Pembangunan untuk Kepentingan Umum), UII Press, Yogyakarta, 2018

Mardiasmo, Otonomi \& Manajemen Keuangan Daerah, Penerbit ANDI, Yogyakarta, 2004

Mertokusumo, Sudikno, Mengenal Hukum Suatu Pengantar, Liberty, Yogyakarta, 2007 


\section{Jurnal}

Amir, Nabbilah, Aspek Hukum Pengaturan Tata Ruang terhadap Alih Fungsi Lahan dalam Rangka Pembangunan Nasional, Justiciabelen, Vol 1, No 1, 2018

Asrun, A. Muhammad, "Hak Asasi Manusia dalam Kerangka Cita Negara Hukum Catatan Perjuangan di Mahkamah Konstitusi)", Jurnal Cita Hukum Fakultas Syariah dan Hukum UIN Jakarta, Vol. 4 No. 1, 2016

Broberg, Morten dan Hans-Otto Sano, "Strengths and weaknesses in a human rightsbased approach to international development - an analysis of a rights-based approach to development assistance based on practical experiences", The International Journal of Human Rights, Vol. 22, No. 5.2017

Dewi, Iga Gangga Santi, “Konflik Tentang Ganti Rugi Non Fisik Pada Pengadaan Tanah Untuk Kepentingan Umum", Masalah-Masalah Hukum, Vol. 46, No 3,2017

M. Dari Arif Mu'allifin," Hubungan Konstitusi dengan Tugas dan Fungsi Negara", Jurnal Ahkam, Vol 4, No. 1, Juli 2016

Manan, Bagir dan Susi Dwi Harijanti, "Konstitusi dan Hak Asasi Manusia”, Jurnal Ilmu Hukum, Volume 3, Nomor 3, Tahun 2016

Rahardjo, Satjipto, "Reformasi Menjadi Hukum Progresif", Unisia,No. 53/XXVII/III/22004

Ridwan,"Arti Penting Asas Keterbukaan dalam Penyelenggaraan Pemerintahan yang Bebas dari Korupsi, Kolusi, dan Nepotisme", Jurnal Hukum, Vol. 27, 11 September 2004

Sayuti, "Konsep Rechstaat dalam Negara Hukum Indonesia", Jurnal Kajian Ekonomi Islam dan Kemasyarakatan, Volume 4, Nomor 2, Desember 2011

Sidharta, B. Arief, "Kajian Kefilsafatan tentang Negara Hukum",Jentera (Jurnal Hukum) "Rule of Law", Pusat Studi Hukum dan Kebijakan (PSHK), Jakarta, edisi 3 Tahun II, November 2004

Syaprillah, Aditia, "Penegakan Hukum Administrasi Lingkungan Melalui Instrumen Pengawasan", Jurnal Bina Hukum Lingkungan , Volume 1, Nomor 1, Oktober 2016

Taringan, Jefri Porkonanta, "Akomodasi Politik Hukum di Indonesia Terhadap Hak Asasi Manusia Berdasarkan Generasi Pemikirannya", Jurnal Konstitusi, Volume 14, Nomor 1, Maret 2017

\section{Peraturan Perundang-undangan}

Undang-Undang Nomor 20 Tahun 1961 tentang Pencabutan Hak-Hak Atas Tanah (Lembaran Negara Republik Indonesia Tahun 1961 Nomor 288, Tambahan Lembaran Negara Republik Indonesia Tahun 1961 Nomor 2324) 
Undang-Undang Nomor 2 Tahun 2012 tentang Pengadaan Tanah Bagi Pembangunan untuk Kepentingan Umum (Lembaran Negara Republik Indonesia Tahun 2012 Nomor 22, Tambahan Lembaran Negara Republik Indonesia Nomor 5280)

Peraturan Presiden 71 Tahun 2012 tentang Penyelenggaraan Pengadaan Tanah Bagi Pembangunan Untuk Kepentingan Umum (Lembaran Negara Republik Indonesia Tahun 2012 Nomor 156)

Peraturan Presiden No. 36 Tahun 2005 tentang Pengadaan Tanah Bagi Pelaksanaan Pembangunan untuk Kepentingan Umum

Keputusan Presiden No. 55 Tahun 1993 tentang Pengadaan Tanah Bagi Pelaksanaan Pembangunan Untuk Kepentingan Umum

Peraturan Menteri Dalam Negeri No. 15 Tahun 1975 tentang KetentuanKetentuan Mengenai Tata Cara Pembebasan Tanah

\section{Sumber Lain}

https:/ /jogja.tribunnews.com/2019/06/27/pembangunan-taman-budayasleman-masih-mencari tanah diakses pada 11 Februari 2020

BKSI, Mencari Format Dan Konsep Transparansi Dalam Penyelenggaraan Pemerintahan Daerah" Disajikan pada seminar "Menciptakan Transparansi Penyelenggaraan Pemerintahan Daerah : Memberdayakan Momentum Reformasi, Makalah, Forum Inovasi dan Kepemerintahan yang Baik, Program Pascasarjana, Program Studi Ilmu Administrasi, Fakultas Ilmu Sosial dan Ilmu Politik, Universitas Indonesia, Depok, 12 Juni 2001

Wawancara dengan Ibu Endang sebagai masyarakat terdampak pengadaan tanah, pada tanggal 24 Januari 2020

Wawancara dengan Ibu NN (disamarkan), sebagai masyarakat terdampak pengadaan tanah, pada tanggal 26 Januari 2020 